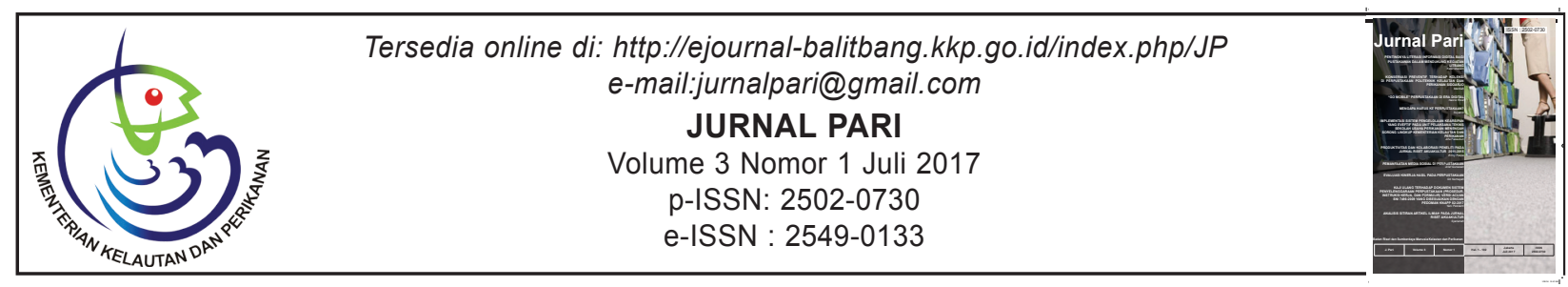

\title{
MENGAPA HARUS KE PERPUSTAKAAN?
}

\author{
Why should we go to library?
}

SUYATNO

Pusat Riset Perikanan

Diterima tanggal : 27 Maret 2017 diterima setelah perbaikan : 23 Mei 2017 disetujui terbit : 28 Juni 2017

\begin{abstract}
ABSTRAK
Jika kita mendengar kata perpustakaan pasti yang terpikir di benak kita adalah tempat tumpukan buku-buku yang sangat membosankan dengan berrbagai masalah didalamnya. Tetapi diluar itu sebenarnya banyak sekali manfaat yang dapat kita peroleh dari suatu perpustakaan selain dari hanya sekedar mencari literature atau informasi. Bagi kamu yang sedang mencari cara belajar yang efektif jangan ragu untuk mencoba belajar di perpustakaan. Laptop kamu rusak dan sedang diservis? Tenang, perpustakaan kampus menyediakan komputer untuk mahasiswanya. Hobi membaca cerpen, menulis atau membaca blog, dan google? Pergi ke perpustakaan yuk!. Bukan hanya pacar yang bisa dijadikan tempat pelepas kepenatan, perpustakaan pun rela menjadi tempat pelepas kepenatan kamu. Sedang butuh waktu untuk menyendiri? Perpustakaan punya ruang yang tepat untuk kamu. Selain mencari ilmu, relasi baru (teman hidup) bisa kamu dapatkan pula dari tempat ini. Ingin browsing chating serta melihat video tanpa harus kehabisan baterai di HP atau laptop silahkan berkunjung ke perpustakaan. Ingin belajar kelompok tapi tidak tahu harus ngumpul dimna, datanglah ke perpustakaan. Pengen liburan murah tapi bermanfaat datanglah ke perpustakaan. Buat anak-anak kita serta adik-adik kita yang masih belajar di PAUD atau Taman kanak-kanak silahkan berkunjung keperpustakaan. Bagi para calon wirausaha atau bahkan wirausaha yang ingin mengembangkan usahanya kunjungiah perpustakaan.
\end{abstract}

Kata kunci: perpustakaan; manfaat;

\section{ABSTRACT}

If we hear the word library must have occurred in our minds is where the pile of books is very boring with various problems in it. But beyond that there are many benefits that we can get from a library other than just looking for literature or information. For those of you who are looking for an effective way of learning do not hesitate to try studying in the library. Your laptop is broken and is being serviced? Calmly, the college library provides computers for students. Hobbies reading short stories, writing or reading blogs, and google? Go to the library! Not just a girlfriend who can be a place fatigue release, the library was willing to be a release your fatigue. Looking for time out alone? The library has the right room for you. In addition to seeking knowledge, new relationships (friends of life) you can also get from this place. Want to browse chating and view videos without having to run out of batteries in handphone or laptop please visit the library. Want to learn group but do not know have to gather where, come to library. Want a cheap but useful holiday come to the library. Create our children and younger siblings who are still studying in early childhood or kindergarten please visit the library. For entrepreneurial candidates or even entrepreneurs who want to expand their business visit the library.

Keyword: library; benefits

Korespondensi penulis:

Gedung BRSDM II lantai 2 Jln. Pasir Putih II, Ancol, Jakarta Utara email : syatsen.90@gmail.com 


\section{PENDAHULUAN}

\section{Pengertian Perpustakaan}

Perpustakaan dibentuk dari kata dasar "pustaka", yang secara harfiah berarti kitab atau buku. Dalam Kamus Besar Bahasa Indonesia, perpustakaan dimaknai sebagai kumpulan bukubuku. Kata perpustakaan yang dalam bahasa Inggris disebut library berasal dari bahasa Latin liber atau libri yang dalam perkembangannya kemudian berubah menjadi librarius, yang maknanya tentang buku (Sulistyo-Basuki dalam Suwarno, 2007). Istilah perpustakaan dalam berbagai bahasa, disebut dengan : bibliotheek (Belanda), bibliothek (Jerman), bibliotheque (Perancis), bibliotheca (Spanyol/Portugis), yang semua itu berasal dari bahasa Yunani, yaitu biblia.

Beberapa pengertian tentang perpustakaan, antara lain :

1. 1. a room or building where a collection of books and newspapers, or things such as films or records is kept to be used by members (sebuah ruangan atau bangunan yang koleksi buku-buku dan surat kabar-surat kabar, atau benda-benda seperti film atau rekamanrekaman, terpelihara dengan baik untuk digunakan oleh para anggotanya) (Chambers Essential English Dictionary, 1995).

2. a collection of books, or a similar collection of things such as films or records (suatu koleksi dari buku-buku atau semacam koleksi dari benda-benda seperti film atau rekamanrekaman) (Chambers Essential English Dictionary, 1995)

kumpulan buku, manuskrip dan bahan pustaka lainnya yang digunakan untuk keperluan studi atau bacaan, kenyamanan atau kesenangan (Webster's Third Edition International Dictionary, 1961) http://aguswahyupriutomo.blogspot. co.id/2015/07/artikel-tentang-perpustakaan-dan. $\underline{\text { html }}$

Perpustakaan adalah institusi pengelola koleksi karya tulis, karya cetak, dan atau karya rekam secara profesional dengan sistem yang baku guna memenuhi kebutuhan pendidikan, penelitian, informasi, dan rekreasi para pemustaka (Perpaturan Ka Perpusnas RI nomor 11 tahun 2015)

Sebuah ruangan, bagian dari sebuah gedung ataupun gedung itu sendiri, yang digunakan untuk menghimpun buku dan terbitan yang biasanya disimpan menurut tata susunan tertentu untuk digunakan pembaca, bukan untuk dijual (Sulistyo Basuki, dalam Sumiati dan Arief, 2004)

Kesimpulanya adalah perpustakaan merupakan tempat untuk melakukan kegiatan kepustakawanan dengan berbagai macam pernakperniknya.

\section{PEMBAHASAN}

Bagi yang ingin mencari bagaimana cara belajar yang efektif jangan ragu untuk mencoba belajar di perpustakaan mengapa bisa dikatakan efektif. Karena belajar di perpustakaan tidak membutuhkan biaya yang besar sedangkan informasi yang didapat banyak sekali. Selain itu banyak sekali fasilitas yang diperoleh jika kita belajar di perpustakaan dari mulai internet gratis, sampai bisa membawa pulang buku jika kita sudah menjadi anggotanya. Bagi para siswa yang sedang belajar di sekolah seperti SD, SMP, SMA perpustakaan juga menyediakan bahan pustaka yang menunjang pelaksaanan program kurikulum di sekolah baik yang bersifat kurikuler, kokurikuler, maupun ekstra kurikuler.

Khusus untuk kamu yang sedang menduduki bangku kuliah jika Laptop kamu rusak atau sedang diservis? Tidak masalah, perpustakaan di kampus menyediakan komputer gratis bagi mahasiswanya. Kejadian seperti ini sering terjadi di kampus apalagi jika sedang banyak sekali tugas kuliah laptop ngehang, error, itu sudah biasa, apa lagi sudah akhir bulan paket internet biasanya sudah mulai habis mau tetring di handphone atau laptop temen gak enak secara masih sama-sama bergantung dari kiriman orang tua. Solusi yang paling jitu jika sudah kejadian seperti ini yaitu datang ke perpustakaan. Tetapi untuk menikmati fasilitas tersebut di perpustakaan tidaklah mudah karena namanya juga fasilitas gratis peminatnya banyak klo sudah begitu pasti terjadi antrian. Solusinya kita harus pintar-pintar memilih waktunya. Waktu yang tepat biasanya di pagi hari karena diwaktu ini belum banyak mahasiswa yang dating ke perpustakaan. Selain itu jaringan internetnya juga masih lancar karena belum banyak yang memakai. Satu lagi agar kita bisa memakai fasilitas internet dengan lancer tanpa ada halangan baik-baiklah dengan petugas perpustakaanya. Kenali lebih dekat tetapi jangan sok dekat, jika sudah dekat jangankan Cuma internet gratis segelas kopipun bisa kamu dapatkan secara Cuma-Cuma. 
Hobi membaca cerpen, menulis atau membaca blog, browsing di google? Silahkan ke perpustakaan Membaca cerpen atau membaca blog serta browsing di google sangat disukai oleh para mahasiswa karena bisa menghilangkan jenuh setelah rutinitas belajar seharian. Untuk bisa membaca cerpen atau blog diinternet diperlukan paket data yang besar jika kita memakai handphone atau laptop pribadi mungkin baru beberapa hari atau minggu sudah habis. Apalagi kegiatan membuat blog sekarang lagi ngetrend sedangangkan proses pembuatanya membutuhkan waktu yang lama untuk itu diperlukan jaringan internet yang setabil dan tentunya gratis. Bagi mahasiswa Akses untuk dapat menyambung ke wifi diperpustakaan biasanya dengan memasukan NIM mahasiswa tersebut dikolom login. Untuk itu perpustakaan harus menyediakan wifi gratis bagi para mahasiswanya yang saat ini kayaknya menjadi kebutuhan wajib bagi perguruan tinggi. Dengan adanya fasilitas ini mahasiswa akan betah lama-lama tinggal di kampus khususnya di perpustakaan. Hal ini membuat pengusaha warnet gulung tikar dan jarang kita jumpai dideket kampus maupun dilingkungan kita.

Bukan hanya pacar atau teman dekat yang bisa dijadikan sebagai pelepas kepenatan, perpustakaan pun rela menjadi tempat pelepas kepenatan kamu. Setelah kita disibukan dengan rutinitas sehari-hari

Untuk mewujudkan semua itu perpustakaan harus berbenah untuk perpustakaan umum harus ditambah lagi fasilitas penunjang agar masyarakat lebih semangat lagi datang ke perpustakaan memang masalah biaya terkadang menjadi kendala utama di semua unit perpustakaan, akan tetapi jika kita sebagai pengelola perpustakaan mau berusaha dengan keras memanfaatkan semua peluang yang ada sehingga semuanya dapat terwujud. Sedikit demi sedikit kita benahi, untuk perpustakaan umum di daerah sekarang pejabat-pejabat di daerah baik propinsi maupun Kabupaten sudah mulai memperhatikan keberadaan perpustakaan. Karena di daerah sekarangi ini sedang berlomba untuk memajukan daerahnya masing-masing dengan berbagai pembangunan yang salah satunya adalah perpustakaan yang dijadikan icon didaerah masing-masing. Hal ini tentu sangat membantu bagi pengelola perpustakaan untuk mengembangkan perpustakaannya, tinggal bagaimana kita sebagai pengelola perpustakaan menciptakan ide-ide baru untuk menciptakan sebuah perpustakaan yang menarik sehingga masyarakat mau dating dan betah berlama-lama di perpustakaan.

Untuk perpustakaan khusus seperti perpustakaan perguruan tinggi, perpustakaan sekolah, perpustakaan masjid dan lainya juga harus dibenahi. Pada perpustakaan perguruan tinggi kebutuhan internet menjadi hal yang wajib dimiliki jika ingin mahasiswanya betah di perpustakaan. Selain itu kemampuan petugas dibidang teknologi informasi juga harus ditingkatkan dari penguasaan office sampai jaringan internet serta bidang teknologi informasi yang lain untuk menunjang kebutuhan mahasiswa yang semakin modern. Kemudian kondisi ruangan perpustakaan harus dibangun senyaman mungkin. Karena kegiatan mahasiswa sekarang lebih banyak berdikusi dan berkomunikasi dengan banyak orang jika ruangannya sempit mahasiswa akan mencari tempat lain sehingga perpustakaan akan ditinggalkan.

Perpustakaan masjid merupakan perpustakaan khusus yang mendukung kegiatankegiatan di masjid yang menaunginya. Fungsi masjid di masa Rosulullah Saw dan para Shohabat (khulafaur Rasyidin) antara lain dijadikan sebagai pusat kegiatan keagamaan (keislaman) dan ibadah khusus; tempat bertemunya umat Islam; pusat dakwah dan pendidikan; tempat kegiatan kemasyarakatan; tempat mencari ketenangan; dan tempat istirahat para musafir. http://www. pksjatiasih.com/peranan-perpustakaan-masjiddalam-pembinaan-umat-islam/.

Di Indonesia masjid belum banyak yang memiliki perpustakaan khusus. Sebagain besar hanya memiliki beberapa ruangan yang dijadikan tempat untuk menyimpan kitab suci Al-Quran, alhadist serta buku-buku tentang Islam serta sebagai tempat untuk mengkaji, belajar Al-quran dan pendalaman agama Islam. Sehingga belum dididrikan perpustakaan khusus untuk mendukung kegiatan di masjid tersebut. Hal ini harusnya menjadi perhatian pemerintah secara penduduk Indonesia mayoritas beragama Islam. Perpustakaan masjid yang bisa dikatakan sudah berjalan sebagian besar hanya di masjidmasjid besar saja. Itupun belum dikelola secara maksimal karena petugasnya merangkap menjadi pengurus masjid. Oleh karena itu perpustakaan masjid perlu mendapatkan perhatin khusus dalam 
pengelolaanya sebelum membangun jaringan internet didalamnya. Perpustakaan masjid yang banyak pengunjungnya biasanya terjadi pada waktu-waktu tertentu seperti di Bulan Puasa atau bulan suci Ramadhan karena diwaktu puasa umat Islam banyak memanfaatkan waktunya di masjid. Dari yang hanya untuk shalat, baca Al-Quran, melakukan kajian sampai dengan yang hanya untuk istirahat melepas lelah serta kegiatan lain di masjid. Pada momen tersebut sebagai pengelola perpustakaan dapat memanfaatkanya untuk promosi memperkenalkan perpustakaan yang ada dimasjidnya. Sehingga diharapkan setelah selseai bulan puasa para pengunjung dapat berkunjung kembali untuk mencari informasi seputar agama islam. Untuk petugasnya diharapkan orang yang sudah mempunyai ilmu agama islam yang mencukupi atau mumpuni. Sebab pengunjung dari perpustakaan masjid bisa dari berbagai kalangan serta bisa dari mualaf yang baru akan mempelajari agama islam.

\section{Perpustakaan sebagai tempat pelepas kepenatan}

Penat menurut Kamus Besar Bahasa Indonesia yaitu merasa letih (sehabis bekerja keras dan sebagainya) http://kbbi.web.id/penat. Pada dasarnya penat datang bukan hanya karena faktor dari dalam diri anda saja, tetapi bisa juga karena faktor dari luar. Penat bisa saja diartikan dengan rasa jenuh, bosan, jengah, dan semua itu adalah hal yang harus diatasi, karena jika rasa penat selalu menghantui anda makan akan berdampak buruk pada kehidupan anda, baik dalam hal pekerjaan, pola hidup, dan sikap atau perilaku. http://www.constiti.com/2013/09/tipsmenghilangkan-rasa-penat.html

Dikota besar dengan rutinitas yang sangat tinggi memudahkan seseorang akan cepat mengalami kepenatan. Hal ini jika dibiarkan secara terus menerus akan mengalami stress sehingga bisa brdampak langsung terhadap fisik seseorang. Untuk itu salah satu cara untuk menghilangkan kepenatan adalah dengan datang mengunjungi perpustakaan. Kita dapat membaca artikel yang bisa menghibur seperti, buku-buku cerpen; komik, atau majalah-majalah yang kekinian, atau hanya sekedar membuka internet untuk membuka informasi yang menghibur sehingga rasa penat kita berkurang sekaligus kita mendapatkan ilmu atau informasi yang bermanfaat. Selain itu jika kita dan keluarga mempunyai waktu senggang kita bisa sama-sama mengunjungi perpustakaan apalagi jika anak-anak kita masih belajar di taman kanak-kanak (TK) atau sudah Sekolah Dasar (SD) hal ini penting sekali untuk mengajarkan pada anak-anak kita untuk terbiasa membaca serta mamperkenalkan perpustakaan kepada mereka sekaligus Memperkenalkan koleksi-koleksi yang ada di perpustakaan tentunya sesuai dengan porsinya.

\section{Sedang butuh waktu untuk menyendiri?}

Menyendiri kadang dibutuhkan oleh seseorang yang sedang dirundung berbagai masalah kehidupan. baik masalah keluarga, masalah pekerjaan, masalah di sekolah, masalah asmara ataupun masalah lainya silahkan berkunjung ke perpustakaan. Dikhawatirkan jika kita sedang mengalami masalah terus kita hanya berdiam diri dirumah akan bisa menambah ruwet masalah yang sedang kita hadapi. Apa lagi jika duduk-duduk dipinggir jalan dengan masalah dipikiran kita bisa fatal akibatnya selain akan merugikan dirikita juga dapat merugikan orang lain. Maka dari itu perpustakaan mungki dapat dijadikan sebagai tempat untuk menyendiri, memang mungkin tidak secara langsung dapat menyelesaiakn masalah yang sedang dialami, akan tetapi perpustakaan bisa dijadikan tempat untuk merenung untuk mencari solusi dari berbagai masalah yang dihadapi tersebut. Atau mungkin bisa sebentar untuk melupakan masalah yang sedang dihadapi karena diselingi dengan membaca artikelartikel yang mungkin senangi. Kalo sudah rileks atau santai biasanya solusi dari berbagai masalah akan didapatkan.

Selain mencari ilmu, relasi baru (teman hidup) bisa kamu dapatkan pula dari tempat ini.

Perpustakaan merupakan salah satu tempat bertemunya berbagai individu dengan berbagai macam latar belakang profesinya. Dari mulai pelajar, guru, dosen, peneliti, pengusaha, dan lain-lainya. Untuk itu jika kita ingin mendapatkan relasi atau kenalan baru silahkan berkunjung ke perpustakaan baik perpustakaan khusus maupun perpustakaan umum. Di perpustakaan kita dapat bersosialisasi dengan berbagai karakter orang disini kita dapat menimba ilmu, bertukar pengalaman, serta memecahkan masalah dengan orang lain yang belum kita kenal. Hal ini akan membuka wawasan kita tentang berbagai hal dan keilmuan dengan orang lain, yang penting kita jangan malumalu untuk memperkenalkan diri, tidak minder serta 
tidak menutup diri kepada orang lain. Bagi anda yang belum memiliki pasangan atau teman hidup bisa juga mencarinya di perpustakaan. Biasanya orang yang dating ke perpustakaan adalah orangorang yang memiliki intelektual tinggi, orang yang haus akan pengetahuan dan informasi. Dijamin jika anda mendapatkan pasangan di perpustakaan pasangan anda adalah orang yang berilmu, memiliki intelektual yang tinggi serta orang yang cerdas. Mungkin cara ini terbilang kuno ketinggalan jaman dan tidak kekinian karena sekarang ini untuk mendapatkan pasangan banyak sekali medianya apa lagi dengan media social. Tetapi apapun medianya tatap muka atau kopdar tetap harus dilakukan untuk itu tempat terbaik untuk melakukan pertemuan adalah di perpustakaan karena bisa menghemat biaya waktu dan tenaga.

Ingin browsing, chating, serta melihat video tanpa harus kehabisan baterai di HP atau laptop silahkan berkunjung ke perpustakaan.

Bagi sebagian orang kegiatan browsing, chating, serta melihat video di internet merupakan kegiatan yang menyenangkan, sehingga bisa berjam-jam dilakukan. Untuk melakukan kegiatan ini dibutuhkan laptop atau handphone dengan kekuatan batere yang penuh. Untuk handphone mungkin masih bisa disambung dengan charger/ alat pengisi daya tambahan tetapi itupun baru beberapa jam sudah habis. Utuk lapotop mau gak mau harus selalu terbubung dengan stopkontak kalo tidak ingin laptopnya mati. Untuk mengatasi hal tersebut perpustakaan menyediakan listrik gratis untuk memenuhi kebutuhan akan daya tersebut guna menjadikan handphone dan laptop kita tetap hidup sehingga kegiatan-kegiatan tersebut diatas bisa terus berjalan.

Ingin belajar kelompok tapi tidak tahu harus ngumpul dimna, datanglah ke perpustakaan

Belajar kelompok bagi sebagian orang sangat dibutuhkan apalagi bagi siswa atau mahasiswa yang sedang mengerjakan tugasnya. Untuk mendukung kegiatan tersebut biasanya dibutuhkan tempat yang representative. Jika dilakukan dirumah biasanya akan mengganggu anggota keluarga dirumah apalagi jika dirumah ada anggota yang masih balita tentunya akan sangat membuat tidak nyaman baik bagi anggota keluarga maupun kita yang akan melakukan tugas kelompok. Untuk mengatasi permasalahan tersebut perpustakaan merupakan salah satu solusinya. Selain aman dan nyaman di perpustakaan membantu kita jika ada referensi tugas yang kurang serta menyediakan informasi yang mungkin kita butuhkan.

\section{PENUTUP}

Mengapa kita harus berkunjung ke perpustakaan?. Selain sebagai tempat berkumpulnya berbagai macam informasi dan literature perpustakaan memiliki manfaat lain diantaranya sebagai tempat untuk belajar yang efektif dan efisien, sebagi tempat untuk melepas kepenatan, sebagai tempat untuk menyendiri, sebagai tempat untuk mendapat teman atau relasi baru, tempat untuk mengerjakan tugas kelompok, utuk melakukan kegiatan browsing, chating, serta melihat video tanpa harus kehabisan baterai di handphone atau laptop. Untuk itu, untuk menjamin kegiatan tersebut terlaksana semua unit perpustakaan baik perpustakaan umum maupun perpustakaan khusus harus berbenah harus diterapkan inovasi baru yang dapat menarik masyaraat untuk berkunjung ke perpustakaan, fasilitas internet yang merupakan kebutuhan pokok bagi masyarakat sekarang harus diadakan atau bagi yang sudah ada jaringan internet harus dimaintenance dengan baik.

\section{DAFTAR ACUAN}

http://aguswahyupriutomo.blogspot. co.id/2015/07/artikel-tentang-perpustakaandan.html

Sumiati, Opong dan Nurahmah Arief. 2004. Pengantar IImu Perpustakaan. Hernandono ed. Jakarta : Perpustakaan Nasional Republik Indonesia

Suwarno, Wiji. 2007. Dasar-Dasar IImu Perpustakaan Sebuah Pendekatan Praktis. Yogyakarta : AR-Ruzz Media

Perpustakaan Nasional, 2015. Peraturan Kepala Perpustakaan Nasional Republik Indonesia Nomor 11 Tahun 2015 tentang Jabatan Fungsional Pustakawan dan Angka Kreditnya. Jakarta: Perpustakaan Nasional RI

http://www.pksjatiasih.com/perananperpustakaan-masjid-dalam-pembinaanumat-islam/.

http://kbbi.web.id/penat. 